\title{
AN ANALYSIS OF THE HUMAN DEVELOPMENT REPORT 2011: SUSTAINABILITY AND EQUITY: A BETTER FUTURE FOR ALL
}

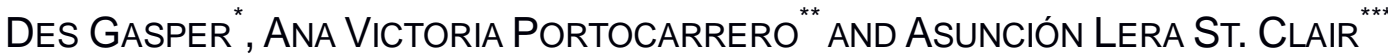

A prefinal draft of a paper prepared for: South African Journal on Human Rights, 29(1), 2013

\begin{abstract}
The Human Development Report 2007/2008 about climate change and development made bold arguments concerning human rights and justice for poor and disadvantaged populations. However, its policy proposals were less bold, looking very similar to those of the World Bank's World Development Report 2010. This article investigates in which direction the thinking on environment and sustainability by UNDP's Human Development Report Office has evolved since 2007/8. A detailed frame- and lexical analysis of the HDR 2011 on Sustainability and Equity shows a markedly technocratic direction, largely apolitical and insensitive to human rights issues and justice, giving a diluted successor to the HDR 2007/2008, now close in perspective to the World Bank. This direction as well as the little attention to the socio-economic and political barriers to sustainability and to climate change impacts we find in the HDR 2011, has implications for the poorest sectors of South African society.
\end{abstract}

Keywords: climate change, development, environment, human rights, problem and policy frames, South Africa, United Nations Development Programme

\section{INTRODUCTION}

A global Human Development Report (HDR) prepared for the United Nations Development Programme (UNDP) appears annually. This series competes with the World Development Report (WDR) series prepared by the World Bank, for the position of the most widely read and influential, agenda-defining, annual report series on international development. The HDR $2000^{1}$ took major steps towards integrating the much longer established framework of human rights with the HDRs' 'human development' conceptual framework, which has been associated especially with Amartya Sen's 'capability approach'. ${ }^{2}$ The HDR 2007/2008 presented the problems that anthropogenic climate change poses for development in terms of human rights

\footnotetext{
* Institute of Social Studies (The Hague), Erasmus University Rotterdam, Netherlands; gasper@iss.nl

** Universidad Centroamericana (UCA), Nicaragua; aportocarrero@ns.uca.edu.ni

${ }^{* \star *}$ Center for International Climate and Environmental Research-Oslo and Christian Michelsens Insitute (CMI)

${ }^{1}$ UNDP 'HDR 2000: Human Rights and Human Development' (2000).

${ }^{2}$ See, for example, A Sen Development as Freedom (1999); also see D Gasper 'Human Development' in J Peil \& I van Staveren (eds) Handbook of Economics and Ethics (2009a) 230, 237; D Gasper 'Human Rights, Human Needs, Human Development, Human Security' in P Hayden (ed) Ashgate Research Companion to Ethics and International Relations (2009b) 329, 355.
} 
violations, with reference to power relations at the global level. ${ }^{3}$ Runaway climate change 'would represent a systematic violation of the human rights of the world's poor and future generations' by current rich polluters. ${ }^{4}$ The HDR 2007/2008 on climate change stood in marked contrast to the equally imposing WDR 2010 on climate change, which adopted a significantly different problem framing and situation diagnosis. ${ }^{5}$ The WDR argued that no reduction in economic growth is necessary, and, in line with established World Bank practice, ${ }^{6}$ avoided the language of human rights. Desmond McNeill and Asuncion Lera St. Clair have argued that the World Bank's treatment of equity has been primarily instrumental, devoid of an intrinsic value for equity and of one of the central foundations of human rights: the intrinsic equal value of all human beings. ${ }^{7}$

Recent articles have compared these two reports in detail, for they are the major statements on climate change from the two leading international development organisations. ${ }^{8}$ In our own analysis, ${ }^{9}$ we compared their Overviews using a frame and content-analysis methodology that focused attention on key terms and framing choices. We contextualised this analysis from studies of the institutions' processes of knowledge production, their sociopolitical environment, and results from earlier work investigating the role of ideas in the multilateral sector. We found something surprising. While the HDR 2007/2008 took a very different stance in comparison to the WDR 2010 in its evaluative language, the policy solutions presented by the two organisations were largely similar. The HDR did not follow through its human rights-related evaluation into a human rights-based policy perspective. Questions arose regarding the reasons for the inconsistency in the HDR 2007/2008, and how the standpoint of the UNDP - in particular that of the semi-autonomous HDR Office (HDRO) - would evolve. ${ }^{10}$

\footnotetext{
${ }^{3}$ UNDP 'HDR 2007/2008: Fighting Climate Change - Human Solidarity in a Divided World' (2007).

${ }^{4}$ Ibid 4.

5 World Bank 'WDR 2010: Development and Climate Change' (2010).

${ }^{6}$ D McNeill \& AL St. Clair 'The World Bank's Expertise: Observant Participation in WDR 2006 Equity and Development' in D Mosse (ed) Terms of Reference: the Anthropology of Expert Knowledge and Professionals in International Development (2011).

${ }^{7}$ McNeill \& St. Clair analyse how the processes of producing and negotiating the completion of the WDR 2006 on equity were marked by an equivocal use of the term equity. The WDR placed more emphasis on an instrumental and economistic sense, and downplayed an intrinsic value. See McNeill \& St. Clair ibid.

${ }^{8}$ K Fløttum \& T Dahl 'Different Contexts, Different "Stories"? A Linguistic Comparison of two Development Reports on Climate Change' (2012) 32 Language and Communication 14; D Gasper, AV Portocarrero \& AL St. Clair 'The Framing of Climate Change and Development: a Comparative Analysis of the Human Development Report 2007/8 and the World Development Report 2010' (2013) 23 Global Environmental Change 28, 39.

${ }^{9}$ Gasper et al ibid.

${ }^{10}$ The HDRO has formal editorial independence in regard to the HDR. However, the office is administratively a part of the UN system and its director is appointed by the UNDP administrator.
} 
The HDR 2011 on sustainability and equity provides a relevant opportunity to address these questions. How embedded is a human rights perspective in UN work on human development, and especially in relation to the looming human rights challenge of anthropogenic climate change? The HDR 2011 appeared in the run-up to the UN conference on Sustainable Development, the Rio+20 conference of 2012, and was titled 'Sustainability and Equity: A Better Future for All'. ${ }^{11}$ As such it constitutes an attempted major statement, intended to structure the new agenda for sustainability to be adopted by 'the international community'. Responses to climate change challenges must be considered in the context of existing poverty, inequalities and marginalisation. Attempted transitions to sustainable development pathways that do not adequately address climate impacts, the costs and possible negative effects of mitigation strategies, limits to adaptation, or negative synergies among diverse policy options, may lead to negative outcomes for poor communities. In this article we ask in which direction did the HDR 2011 move in relation to the schizophrenic stance on climate change seen in the HDR 2007/2008. We also ask to what extent the HDR 2011 met its own demands to integrate equity in discussions about sustainability.

Thus this article analyses the HDR 2011 with emphasis on the treatment of climate change and the poor, human rights, and North-South relations. We give special attention to the report's relevance to Africa, the poorest continent, and its references to South Africa, a country with a medium Human Development Index (HDI), a growing economy and increasing $\mathrm{CO}_{2}$ emissions, but high inequality and persistent poverty, in order to illustrate how issues of growth, inequality, climate change and poverty are intertwined and how these are handled in the report. We argue that while the HDR 2007/2008 had taken some important steps in bringing a human rights perspective into the framing of climate change and its importance for the poor, the HDR 2011 on environmental sustainability and equity has stepped back. It downgrades the urgency of climate change impacts and of countering its causes. Moreover, it puts forward a weakened definition of sustainable development compared to the widely used definition of the Brundtland Report, ${ }^{12}$ and it distances itself from human rights concerns, from the political barriers to sustainability, and from the structural causes of poverty and inequality as key determinants of social and environmental vulnerability.

\footnotetext{
${ }_{11}^{11}$ UNDP 'HDR 2011: Sustainability and Equity: A Better Future for All' (2011).

${ }^{12}$ World Commission on Environment and Development (WCED) 'Our Common Future' (1987).
} 
Part 2 looks at the HDR 2011's Foreword. Part 3 examines the report's Overview in detail, page by page. Part 4 summarises the framing provided by the report's Overview, its inclusions and exclusions, and compares them with those in the Overviews of the HDR 2007/2008 and the WDR 2010; and then analyses the lexical choices in these Overviews, as a further test of our interpretation of the framings. Part 5 considers the treatment of Africa the continent likely to be hardest hit by climate change - and particularly of South Africa, in this case in the HDR 2011 as a whole, with reference again to the patterns of inclusion and exclusion of issues and the degree of adequacy of the analysis. Part 6 concludes.

In the remainder of this Introduction we outline the scope of the HDR 2011 and of our methods for investigation. The full report on sustainability and equity is a book-length study of about 125 double-columned pages; the HDR 2011 also contains almost 60 pages of tables of human development data. We concentrate on the report's Overview, because it is a large selfcontained document, and is the part of the report that has by far the largest audience and is correspondingly prepared with special attention. Most of the HDR audience only reads the Overview. Given this, we will look at the self-contained version of the HDR 2011 Overview, which is found in the separate Summary file available on the HDR website. ${ }^{13}$ It consists of 15 double-spaced pages (in contrast to the 12-page version in the full report). This version incorporates into the Overview selected tables and figures from the full report. The Summary also contains the Foreword, of two pages, and five pages of selected key human development tables. This is unusual - the HDR 2007/2008 Overview did not add such a mass of data - but it matches the line of argumentation in the HDR 2011, much of which is generalised in terms of countries, which are grouped into four categories: very high human development; high human development; medium human development; low human development. The selected tables rank 187 countries in these terms. It is worth adding that the HDR 2011 is a much smaller document than the HDR 2007/2008 on climate change: the earlier study was over 220 pages long, and its Overview was almost double the length of that for 2011, reflecting a more complex and ambitious argumentation.

\footnotetext{
${ }^{13}$ See UNDP 'HDR 2011: Sustainability and Equity: A Better Future for All' (2011) Overview $<$ http://hdr.undp.org/en/media/HDR_2011_EN_Overview.pdf>.
} 
Table 1: Structure of HDR 2011

\section{The complete report}

Chapter 1 . Why sustainability and equity?

1. Are there limits to human development?

2. Sustainability, equity and human development

3. Our focus of inquiry

Chapter 2. Patterns and trends in human development equity and environmental indicators

1. Progress and prospects

2. Threats to sustaining progress

3. Success in promoting sustainable and equitable human development

Chapter 3.Tracing the effects - understanding the relations

1. A poverty lens

2. Environmental threats to people's wellbeing

3. Disequalizing effects of extreme events

4. Disempowerment and environmental degradation

Chapter 4. Positive synergies - winning strategies for the environment, equity and human development

1. Scaling up to address environmental deprivations and build resilience

2. Averting degradation

3. Addressing climate change - risks and realities

Chapter 5. Rising to the policy challenges

1. Business-as-usual is neither equitable nor sustainable

2. Rethinking our development model-levers for change

3. Financing investment and the reform agenda

4. Innovations at the global level

Tables

\section{The Summary}

Foreword by Helen Clark

Overview

Section 1 . Why sustainability and equity?

1. The case for considering sustainability and equity together

2. Some key definitions

Section 2. Patterns and trends, progress and prospects

Section 3. Understanding the links

1. Environmental threats to selected aspects of human development

A Bad environments and health overlapping deprivations

A Impeding education advances for disadvantaged children, especially girls

A Other repercussions

2. Disequalizing effects of extreme weather events

3. Empowerment - reproductive choice and political imbalances

A Gender inequality

A Power disparities

Section 4. Positive synergies - winning strategies for the environment, equity and human development

1. Access to modern energy

2. Averting environmental degradation

Section 5. Rethinking our development model levers for change

A Integrating equity concerns into green economy policies

A A clean and safe environment - a right, not a privilege

A Participation and accountability

A Financing investments: where do we stand?

A Closing the funding gap: currency transaction tax - from great idea to practical policy

A Reforms for greater equity and voice

Tables 
We will present a frame-analysis of what has been included and what excluded in the HDR 2011 Overview, and use lexical analysis (study of word choice) to examine how what is included has been characterised and described. ${ }^{14}$ As an initial example, Table 1 presents a comparison of the scope of the full report and of its Overview. Naturally there is a close correspondence, but missing from the Overview are sections corresponding to those in the full report on 'Are there limits to human development?', 'A poverty lens', 'Scaling up to address environmental deprivations and build resilience', 'Addressing climate change - risks and realities', and 'Business-as-usual is neither equitable nor sustainable'. In the other direction, 'Access to energy' appears as a section in the Overview but not in the full report. Table 1 highlights the discrepant sections. The Overview is the public face of the report, the section read by most journalists, administrators or students. Its set of topics seems blander, more technocratic, and less challenging to business-as-usual. The exclusion of the indicated sections is relevant, for some of them contain information that helps in nuancing and even countering some of the assertions made in the Overview, as we will explain later. The exclusions are also relevant for the way in which the challenges posed by climate change in Africa are depicted, favouring a focus on hoped-for win-win-win solutions rather than addressing the difficult structural causes of people's vulnerability.

Beneath the level of section headings, what do the sections contain? Whereas the full report includes a modest but substantive section on human rights to a safe and sufficient environment, ${ }^{15}$ using Martha Nussbaum's language of people's underlying 'rights to bodily health and integrity and to enjoyment of the natural world', ${ }^{16}$ the Overview races through 'A clean and safe environment - a right not a privilege' in three paragraphs. The condensation ratio is far greater here than, for example, for the technical economic topic of the Multidimensional Poverty Index (MPI), which receives nine paragraphs in the Overview. ${ }^{17}$ The treatment of rights in the Overview shrinks to a mention of how legalised rights 'can be effective', ${ }^{18}$ without attention to their grounding and justification.

\footnotetext{
${ }^{14}$ For outlines of the methods employed, see RJ Alexander Framing Discourse on the Environment: a Critical Discourse Approach (2009); R Schmidt 'Value-Critical Policy Analysis' in D Yanow \& P Schwartz-Shea (eds) Interpretation and Method (2006); T van Dijk (ed) Discourse Studies. A Multidisciplinary Introduction (2011); D Yanow Conducting Interpretive Policy Analysis (2000).

${ }^{15}$ HDR 2011 (note 11 above) 86-8.

${ }^{16}$ Ibid 86.

17 See UNDP 'HDR 2011: Sustainability and Equity: A Better Future for All' (2011) Summary $<$ http://hdr.undp.org/en/media/HDR 2011 EN Summary.pdf> 7-8.

${ }^{18}$ Ibid 12.
} 
Overall, our article aims to throw light on: what principles guide the work on sustainability by the official champion of the human development approach, the HDRO in the UN, and the degree to which human rights concerns and the interests of poor people are as yet reflected there; whether the incomplete steps towards incorporating such concerns that were taken in the HDR 2007/2008, with respect to threats arising from climate change, have been maintained and taken further, or lost and replaced by something else; and, if not maintained and extended, what are the implications of such a failure to adopt a human rights orientation in response to the threats brought by climate change, for the human rights of poor people everywhere, and not least in South Africa. ${ }^{19}$

\section{FOREWORD TO THE HDR 2011}

The Foreword is signed by Helen Clark, former prime minister of New Zealand, Administrator of the UNDP since 2009 and the first woman to lead the organisation. It opens by pointing to the importance of seeking consensus at the 2012 Rio de Janeiro meeting, on 'global actions to safeguard the future of the planet and the right of future generations everywhere to live healthy and fulfilling lives'. ${ }^{20}$ It states that ' $[T]$ his is the great development challenge of the $21^{\text {st }}$ century'. The emphasis here is 'on the planet' and on 'future generations', rather than on current generations of people suffering the consequences of climate change and poverty. Intragenerational justice is considered in the course of the report, but it is not part of the 'great development challenge' posed in this introductory paragraph.

The Foreword presents the report's main idea as follows: 'sustainability is inextricably linked to basic questions of equity - that is, of fairness and social justice and of greater access to a better quality of life'. ${ }^{21}$ And it continues by stating that sustainability 'is fundamentally about how we choose to live our lives, with an awareness that everything we do has consequences for the 7 billion of us here today, as well as for the billions more who will follow'. ${ }^{22}$ The 'we' here is all humanity. This initial treatment of humanity as one is important, though it needs to be followed by disaggregation, otherwise it can erase issues of

\footnotetext{
${ }^{19}$ See also D Gasper 'Climate Change - the Need for a Human Rights Agenda within a Framework of Shared Human Security' (2012) 79 Social Research: an International Quarterly of the Social Sciences 983, 1014.

${ }^{20}$ HDR 2011 (note 11 above) ii.

${ }^{21}$ lbid.

22 Ibid.
} 
power imbalances between people in the global North, whose actions have had bigger consequences in the lives of everybody else in the world, and people of the global South, whose decisions are less influential in the lives of those in powerful positions.

The word 'power' is indeed mentioned in the fifth paragraph of the Foreword, referring to two levels at which power disparities shape the burdens and deprivations of poor people. The first level is the nation, where 'power disparities and gender inequalities ... amplify the effects of income disparities'; and the second level is global, where 'governance arrangements often weaken the voices of developing countries and exclude marginalized groups ${ }^{23}$ Although power imbalances are identified at these two levels, only one of them is then mentioned in the action alternatives proposed by UNDP's administrator in the Foreword: the national. The Foreword specifically suggests that:

[s]uccessful approaches rely on community management, inclusive institutions that pay particular attention to disadvantaged groups, and cross-cutting approaches that coordinate budget and mechanisms across government agencies and development partners. ${ }^{24}$

The emphasis is on the national and sub-national, and the role of the global is mainly for financing, which has been its traditional official role. The Foreword does not follow up the impact of power imbalances at the global level; instead it goes further in relation to the national level, advocating investments in renewable energy, water and sanitation and reproductive health care. The Foreword closes with messages about the opportunity that Rio 2012 represented to reach a 'shared understanding' of how to move forward. ${ }^{25} \mathrm{~A}$ key phrase, which captures the role of the global North in this 'shared understanding' is: 'Hope rests on new climate finance': more funds, and directing them 'towards the critical challenges of unsustainability and inequity'. ${ }^{26}$

According to the Foreword, '[u]nderstanding the links between environmental sustainability and equity is critical if we are to expand human freedoms for current and future generations' ${ }^{27}$ The emphasis is on 'expanding' human freedoms, not explicitly on constraining the excessive freedoms of some groups that bring damage to fundamental freedoms of others.

\footnotetext{
${ }^{23}$ Ibid.

24 Ibid.

${ }^{25}$ Ibid iii.

${ }^{26} \mathrm{Ibid}$

${ }^{27}$ Ibid ii.
} 
The liberal conception that development is about how individuals 'choose to live [their] lives', which we cited earlier, can sometimes be in tension with sustainability and equity and with seeking common and public goods. In general terms, equity and sustainability require, on the one hand, actions to expand some people's freedoms from fear and from want (meaning nonfulfilment of basic needs), and on the other hand actions to restrict people's freedoms to accumulate at the expense of damaging others and the environment. We will see that the emphasis of the report is on the first set of actions, focusing on the poor and disadvantaged in the world, and not on the actions of the rich and on the need to design also some restrictions to cope in particular with the emissions problem. The Overview declares that 'people's chances at better lives should not be constrained by factors outside their control', ${ }^{28}$ a sentiment that is intended to apply to the poor; but that is in danger of being converted into a slogan that provides protection for the rich against taxation and against regulation to control their actions that harm others.

Sometimes a report's Foreword pulls in a different direction to the report itself, when an organisational apex dissociates itself from the ideas of a subsidiary. Some such tensions existed between the human rights perspective in the HDR 2007/2008 and the Foreword written by the then UNDP Administrator, long-time World Bank official Kemal Dervis. But, whereas the HDR 2007/2008's title was 'Fighting Climate Change: Human Solidarity in a Divided World', the title of the HDR 2011 and of its Overview is far blander: 'Sustainability and Equity: A Better Future for All'. Reference to human solidarity in order to counter global divisions, and to the language of human rights, which was often used in the HDR 2007/2008, are very largely replaced by the vaguer language of 'equity', as used by the WDR 2010. ${ }^{29}$ Similarly, whereas the cover of the HDR 2007/2008 portrayed an image of the world in red, with a silhouette of a person looking at the world, the HDR 2011 cover has a geometrical figure: a square that balances on one vertex. It has no personal element and appeals not to compassion and responsibility but to a purely abstract notion of equity. The cover matches an equally abstract diagram used in the report to analyse possible trade-offs between equity and sustainability.

From reading the Foreword we have identified some of the issues whose treatment in the HDR 2011's Overview deserve examination: the degree of attention to regulating

\footnotetext{
${ }^{28}$ Ibid 1.

${ }^{29}$ Gasper et al (note 8 above).
} 
excessive and damaging freedoms, in addition to promoting expansion of freedoms; the degree of attention to the activities and responsibilities of rich persons, not only poor persons; and the degree of attention to the development, activities and responsibilities of rich countries, not only poor countries.

\section{MAIN Themes IN THE HDR 2011 OVervieW}

The Overview opens by emphasising the links between sustainability, equity and human development, stating that environmental degradation intensifies inequality through adverse impacts on already disadvantaged people, and that inequalities in human development amplify environmental degradation. The report aims to point to pathways that can achieve human development together with sustainability and equity. ${ }^{30}$

\section{(a) Section on 'Why sustainability and equity?'}

The opening section proposes that environmental sustainability and equity 'are fundamentally similar in their concern for distributive justice ${ }^{31}$ yet even today these topics are approached separately in many cases. Sustainability reflects a concern for future generations, and equity reflects a concern for those in current generations who are disadvantaged. Next the concept of human development is presented, using Sen's conceptualisation, ie expansion of the field of attainable valued outcomes. As noted earlier, the focus on expanding some people's choices leaves out of focus the question of constraining some others' freedoms. This is of central importance as sustainability refers to ecological limits that logically imply limits on humans' appropriate freedoms to use nature. Not surprisingly, the formulation then given by the report of the concept of sustainable human development - 'the expansion of the substantive freedoms of people today while making reasonable efforts to avoid seriously compromising those of future generations', ${ }^{32}$ represents a major weakening of the 1987 Bruntland Commission definition. That referred to development, which 'meets the needs of

\footnotetext{
${ }^{30}$ Overview (note 13 above) 2.The HDRs of the 1990s that elaborated on the concept of human development incorporated sustainability and equity, as in the HDRs of 1996 and 1997. The usage in the HDR 2011 appears to shrink the concept to, for example, what is covered by the Human Development Index.

${ }^{31}$ lbid 1.

32 lbid 2 (emphasis added).
} 
the present without compromising the ability of future generations to meet their own needs'; ${ }^{33}$ it had a focus on outcomes not just efforts and left no room for equivocation about what is 'serious' damage.

The report advocates an approach to environmental sustainability that 'favours the position of preserving basic natural assets and the associated flow of ecological services' ${ }^{34}$ and argues that this aligns with human rights-based approaches to development. But the argument is a mere claim, since no specifics are given to demonstrate how this focus on preserving environmental assets has direct or indirect consequences for rights. At the same time, it makes the case for a framework that acknowledges that sustainability and equity are not necessarily mutually reinforcing, 'for example if [pro-environment measures] constrain economic growth in developing countries'. ${ }^{35}$ The report encourages us to give special attention to trade-offs between these objectives and to identifying policies that show 'positive synergies': what they call 'win-win-win solutions that favour sustainability, equity and human development'. 'Win-win' is a concept for describing when more than one group gains, but here it is adapted to describe how more than one objective can be promoted. It is a part of managerial jargon widely used in dominant framings of climate and development, such as that presented in the WDR 2010. Moreover, there is a switch in the definition of sustainable development from referring to the lives of specific groups of people to referring to national averages and aggregates for achievement of objectives. This stands in contrast to the humanistic language chosen in the HDR 2007/2008, which repeatedly openly emphasised the lives and livelihoods of recognisable groups of persons, including in its Overview: 'rural communities in Bangladesh, farmers in Ethiopia and slum dwellers in Haiti'. ${ }^{37}$ Such language has disappeared in the HDR 2011 Overview.

\section{(b) Section on 'Patterns and trends, progress and prospects'}

This section in the Overview argues that: the links between the HDI (particularly its income component) and environmental degradation are not linear; the poor are affected

\footnotetext{
${ }^{33}$ WCED (note 12 above).

${ }^{34}$ Overview (note 13 above) 2.

${ }^{35}$ Ibid.

${ }^{36}$ lbid.

${ }^{37}$ Gasper et al (note 8 above).
} 
disproportionately by climate change; but win-win-win solutions can be enacted, so growth does not have to be unequal and unsustainable.

It first examines a range of predictions related to environmental degradation and considers the implications for human development. According to two simulations prepared for the report of the consequences if climate change is not properly addressed, the global HDI in 2050 will be eight or 15 per cent lower than in a baseline scenario which avoids those consequences, due to negative impacts on agricultural production, access to clean water and improved sanitation, etc. 'These projections suggest that in many cases the most disadvantaged people bear and will continue to bear the repercussions of environmental deterioration, even if they contribute little to the problem. ${ }^{38}$ The scale and significance of these repercussions is in fact seriously concealed by an aggregated index like the HDI, which sums up achievements for all inhabitants of a country or region. Such an index is misleading and inadequate for conveying the scale of impacts on poor people, many of whom may fare far worse than does the national or regional average. Unlike the HDR 2007/2008 which spoke openly of the tens and hundreds of millions of poor people who would be seriously and sometimes fatally hit by these 'repercussions', the HDR 2011 loses such information in the almost useless hyper-aggregated category of global HDI. The sacrifice of many people at the margins of global society becomes virtually invisible under the veil of the global HDI figure.

Moreover, there is no balanced treatment of the structural causes of current nonclimatic and non-environmental stressors that lead towards low human development levels in the future. This is in striking contrast with current scholarship on the human dimensions of climate change and on adaptation research, for example. It is widely recognised that structural factors and drivers of poverty are central hindrances for future resilience, limit adaptation options and may even lead to maladaptation. ${ }^{39} \mathrm{~A}$ discussion on specific constraints towards sustainability posed by existing vulnerabilities is absent in chapters of the report where these constraints would logically play a central role. There is one single reference to poverty in the Chapter 1 'Why Sustainability and Equity?' and zero references to Africa, the poorest continent. Yet this is the chapter that discusses the limits to human development. The

\footnotetext{
${ }^{38}$ Overview (note 13 above) 3.

39 J Barnett \& S O'Neill 'Maladaptation' (2010) 20 Global Environmental Change 211; L Jones \& E Boyd 'Exploring Social Barriers to Adaptation: Insights from Western Nepal' (2011) 21 Global Environmental Change 1262; E Marino \& J Ribot 'Adding Insult to Injury: Climate Change and the Inequities of Climate Intervention' (2012) 22 Global Environmental Change 323.
} 
main references to Africa and to poverty are in relation to what the report calls win-win-win strategies. This centres the reader's attention on changes in the South towards sustainability rather than on required changes in the unsustainable rich North, and it avoids contextualising the limits to such a transition that are posed by low human development.

Another notable choice in aggregation occurs when the Overview explains that 'three quarters of the growth in emissions since 1970 comes from low, medium and high HDI countries', adding though that 'overall levels of greenhouse gases remain much greater in very high [HDI] countries' ${ }^{40}$ It is not clear why the report puts high HDI countries in the same group with medium and low HDI countries; separating these countries could be more revealing. For example, what is the share of low HDI countries in the growth of emissions since 1970? Implicitly the report responds instead to a discussion agenda set by the remaining group, the very high $\mathrm{HDI}$ countries. At the same time it makes clear that '[e]missions per capita are much greater in very high HDI countries than in low, medium, and high HDI countries combined, because of more energy-intense activities'. ${ }^{41} \mathrm{~A}$ person in a very high HDI country accounts for more than 30 times the carbon dioxide emissions per person in a very low HDI country. In addition, the Overview notes that the current economic relationships between countries allow the allocation of carbon-intensive production to poor countries while its output is exported for consumption in rich countries. ${ }^{42}$ Deepening the comparisons of the environmental impacts attributable to different countries in order to reflect this could well have been done, but was not.

The Overview suggests next that 'where the link between the environment and quality of life is direct, as with pollution, environmental achievements are often greater in developed countries, [and] where the links are more diffuse, performance is much weaker'. ${ }^{43}$ It gives three findings that support this general view. First, household environmental deprivations (indoor air pollution, inadequate access to clean water and improved sanitation) decline as the HDI rises. However, although these household deprivations can be seen as environmental issues, they should not be compared with urban air pollution or greenhouse gas (GHG) emissions. They are poverty issues, whereas urban air pollution and GHG emissions are consequences of development-as-usual models. Household environmental deprivations are

\footnotetext{
${ }^{40}$ Overview (note 13 above) 3.

${ }^{41}$ Ibid.

42 lbid.

${ }^{43}$ Ibid 4.
} 
issues that should be addressed as poverty-related or developmental problems, while the main environmental issues at stake in the sustainability debates are the ones in which developed countries are more involved and developing countries suffer the first and more intense impacts of climatic change.

The full report's section on 'a poverty lens' - which as we saw lacks a counterpart section in the Overview - discusses the variables used as indicators of environmental deprivations: water, sanitation, cooking fuel. The section admits that:

[t]he three environmental deprivations were selected as the best comparable measures across countries, but other environmental threats and direct impacts of climate change may be equally or more acute at the local or national level. Flooding may be a more pressing concern for poor households in Bangladesh, for example, than access to water. ${ }^{44}$

By selecting three variables that are more linked to poverty than to impacts of unsustainable behaviour on the poor, the focus shifts to developing countries and away from the sources of unsustainability. If floods, for example, were the focus we would consider more the causal links between GHG emissions and environmental and social disasters. The examples used, such as access to sanitation and modern cooking fuels, do not make those links visible, and hide from view the consumption and production patterns in rich countries.

Second, environmental risks that have community effects (like urban air pollution) seem to rise and then fall with development. However, one can note that the U-shape partly arises because some of the activities that create urban air pollution are moved from richer to poorer countries. Environmental risks that have global effects (notably GHG emissions) typically rise with the HDI. According to the report, "[t]he HDI itself is not the true driver of these transitions', and while incomes and economic growth 'have an important explanatory role for emissions ... the relationship is not deterministic either', since for example 'largescale commercial use of natural resources has different impacts than subsistence exploitation'. 45 'Several countries have achieved significant progress both in the HDI and in equity and environmental sustainability, ${ }^{46}$ the win-win-win solution.

The report shows a table of good performers, which includes Costa Rica, Germany,

\footnotetext{
${ }^{44}$ Ibid 49 (emphasis added).

${ }^{45}$ Ibid 4.

${ }^{46}$ Ibid.
} 
Philippines and Sweden. ${ }^{47}$ It concludes that 'across regions, development stages and structural characteristics countries can enact policies conducive to environmental sustainability, equity and the key facets of human development captured in the $\mathrm{HDI}^{\prime}{ }^{48} \mathrm{The}$ win-win-win solutions that these countries illustrate are in terms of three criteria: global threats, local impacts, and equity and human development. The global threats considered are GHG emissions, deforestation and water use. Sweden and Germany comply with all the criteria except for GHG emissions. That the report chooses Germany and Sweden as examples of win-win-win policies, even though neither performs adequately by the GHG emissions criterion, ${ }^{49}$ shows its downgrading of climate change and of the global poor. Thus not included in its estimation of win-win-win performance are the poorer groups in tropical and subtropical zones who are those most affected by climate change impacts of emissions in Germany, Sweden and elsewhere in the North - as was eloquently described in the HDR 2007/2008.

Immediately after presenting Germany and Sweden as good examples, the Overview exposes 'environmental deterioration on several fronts [elsewhere], with adverse repercussions on human development', ${ }^{50}$ such as land degradation due to soil erosion and overgrazing, unsustainable water use in agriculture, and deforestation, described as a 'major challenge', especially in Latin America and the Caribbean, sub-Saharan Africa, and the Arab States. ${ }^{51}$ This geographical focus is defended in terms of the bigger impacts of environmental degradation and climate change on those areas, ${ }^{52}$ given the higher dependency of poor people on natural resources to make a living, the higher dependency of women on forests and fishery, the greater adverse consequences of environmental degradation faced by women in poor countries because they are disproportionately involved in subsistence farming and water collection, and the greater adverse impacts on indigenous people who also rely heavily on natural resources. The Overview notes in passing that '[e]vidence suggests that traditional practices can protect natural resources, yet such knowledge is often overlooked or downplayed'. ${ }^{53}$ This major issue itself then receives no further attention. Even in the full report there are only two brief references (in Chapter 4). Also unexplored is the evidence that high

\footnotetext{
${ }^{47}$ Ibid 5.

48 lbid.

${ }^{49}$ See Table 1 of the Summary (note 17 above) 5 .

${ }_{51}^{50}$ Overview (note 13 above) 5.

51 lbid 5.

52 lbid 6.

${ }^{53}$ lbid.
} 
health achievements may be correlated with lower carbon emissions whereas high incomes are not. ${ }^{54}$

While the Overview's global analysis allows us to see the role of high HDI countries in climate change (specifically their responsibility for GHG emissions), the local analysis that follows, and the emphasis on problems of the use of land, water and forests, allows the report to shift our attention to low-income regions and away from regions such as the United States and Europe, where the biggest problems of GHG emissions have been and continue to be. The report focuses on national and local levels in less developed countries, downgrading the other side of the coin: the need for changes in highly developed countries.

\section{(c) Section on 'Understanding the links'}

This section of the Overview considers links between environment and equity, including with reference to gender roles and empowerment. It starts by emphasising that most disadvantaged people carry a double burden of deprivation: they are more vulnerable to the wider effects of environmental degradation, and they also have to cope with 'threats to their immediate environment posed by indoor air pollution, dirty water and unimproved sanitation' ${ }^{55}$ But the report focuses more on diverse poverty issues than on the enormous longer-run implications of climate change. 'Climate change' is referred to only 23 times in the Summary for the HDR 2011, compared to 175 times in the Summary for the HDR $2007 / 2008 .^{56}$ The latter is somewhat longer (31 pages compared to 26 pages), and the former covers more aspects of environment; but still a major shift in focus is evident, which is seen in the frequency of usages of the term, 12.6 uses per 1,000 words in the HDR 2007/2008 versus 2.8 in the HDR 2011. This trend is maintained in the full report. While climate change is used 1,247 times in the HDR 2007/2008, it is mentioned 18 per cent as often in the HDR 2011 (229 times). Furthermore, most of the central points of an important section of Chapter 2 that addresses climate change are missing in the Overview. That section makes bold statements regarding consumption patterns and carbon emissions, carbon-intensive production, trade and shifts of carbon emissions, and who the net importers are of carbon and wood.

\footnotetext{
${ }^{54} \mathrm{~J}$ K Steinberger, J Timmons, R Peters, \& G Baiocchi 'Pathways of Human Development and Carbon Emissions Embodied in Trade' (2012) 2 Nature Climate Change 81.

${ }^{55}$ Overview (note 13 above) 7.

${ }^{56}$ We include in both cases the report's Forewords.
} 
In contrast, the section in the Overview elaborates on the pervasiveness of environmental deprivations among the multi-dimensionally poor. ${ }^{57}$ Indeed it argues that these deprivations - in access to modern cooking fuel, clean water, and basic sanitation 'disproportionately contribute to multidimensional poverty'. ${ }^{58}$ But what deserves to be called an environmental deprivation and what is simply an income poverty or economic poverty issue? No doubt, if these economic poverty issues are also called environmental deprivations, it is logical to say that the environmental deprivations contribute to poverty. But to focus on these 'environmental deprivations' at the expense of looking at impacts of climate change appears misguided.

The Overview then describes a series of familiar links, from the 'environmental deprivations' and other environmental degradation, to deterioration in poor people's capabilities and lives. Less routinely, it notes that extreme weather events have disequalizing effects, and greater exposure to extreme weather events substantially reduces a country's HDI.

Also novel, but problematic, is a proposition that ' $[\mathrm{t}]$ ransformations in gender roles and empowerment have enabled some countries and groups to improve environmental sustainability and equity, advancing human development'. ${ }^{59}$ In particular, 'in countries where effective control of reproduction is universal, women have fewer children, with attendant gains for maternal and child health and reduced greenhouse emissions' [and] 'evidence suggests that if all women could exercise reproductive choice, population growth would slow enough to bring greenhouse gas emissions below current levels' ${ }^{60}$ Yet, as noted earlier in the Overview, emissions per capita are very unequal: $\mathrm{CO}_{2}$ emissions per person in a very high HDI country are 30 times more than for a person in a very low HDI country. ${ }^{61}$ This means that, even if it was true that overall emissions would decrease if women in poor countries had less children, the impact of such policies would be far less than from the reduction of emissions in rich countries. Considering this, it is perhaps bizarre to suggest population control in the global South in order to reduce GHG emissions. The data lead us rather towards a call for changes in the patterns of production and consumption in the global North. Further, the data show that

\footnotetext{
${ }^{57}$ Overview (note 13 above) 7.

58 Ibid.

59 lbid 9.

${ }^{60}$ Ibid 10.

${ }^{61}$ lbid 3.
} 
precisely in the global North, where more gender equality has been achieved, dramatically higher per capita GHG emissions are produced.

This has implications too for two further links proposed in the section: first, that women's political participation has important implications for sustainability and equity:

because women often show more concern for the environment, support proenvironmental policies, and vote for proenvironmental leaders, their greater involvement in politics and in nongovernmental organizations could result in environmental gains, with multiplier effects across all the Millennium Development Goals. ${ }^{62}$

Given the patterns observable in rich countries with relatively high participation by women but also very high GHG emissions, the proposed link seems at best a weak one. Similarly, the report states that:

political empowerment at the national and subnational levels has been shown to improve environmental sustainability [and that] while context is important, studies show that democracies are often typically more accountable to voters and more likely to support civil liberties. 63

Yet many countries with stronger democracies are those with stronger $\mathrm{CO}_{2}$ footprints, which refutes any simple relationship between democracy, sustainability and equity. The section itself adds that even within democratic countries the needs and views of the most affected groups are often not reflected in policy priorities, and that the most important issue to solve is power imbalances.

Regarding what the section does not cover, issues about imbalances between countries in terms of power to set the agenda on climate change are not mentioned. The Foreword's warning that power disparities at the global level 'weaken the voices of developing countries and exclude marginalized groups', ${ }^{64}$ is not followed up.

\section{(d) Section on 'Positive synergies - winning strategies for the environment, equity and human development'}

This section of the Overview discusses the win-win-win strategies that are to be created by

\footnotetext{
62 Ibid 10.

63 lbid.

${ }^{64}$ Summary (note 17 above) ii.
} 
governments, civil society, private sector actors and development partners. Although effective solutions should be context specific, there are some principles that could work across countries, according to the Overview. At the local level, it stresses the need for inclusive institutions, and at the national level it aims for scaling-up of successful innovations and policy reform. The international/global level remains absent. The emphasis is on what has to be done at local and national levels, and specifically in developing countries. In the full report too, while some additional references are made in relation to power imbalances in decisionmaking processes at the global level, when it comes to the solutions these imbalances are only addressed by reference to new financing mechanisms.

One specific example of proposed win-win-win strategies concerns 'Access to modern energy'. The subsection starts by asking: 'Is there a trade-off between expanding energy provision and carbon emissions?', and the response is 'not necessarily', since '[t]here are many promising prospects for expanding energy without a heavy environmental toll'. ${ }^{65}$ For example, off-grid decentralised options are, according to the report, 'technically feasible for delivering energy services to poor households and can be financed and delivered with minimal impact on the climate' ${ }^{6} 6$ 'Providing basic modern energy services provision for all would increase carbon dioxide emissions by only an estimated 0.8 percent'. ${ }^{67}$ The challenge is to expand access to global energy supply with renewables at a scale and speed that will improve poor people's lives. But while the report addresses the problem of avoiding increased impact on the climate, it does not address the problem of how to decrease that impact from current unsustainable levels. Neither does it address questions of unequal access to existing energy sources, as we shall see in its discussion of South Africa.

In a section titled 'Scaling up to address environmental deprivations and build resilience' (which has no counterpart in the Overview), the full report takes a conservative position in relation to cuts of emissions, stating that '[p]olicies to cut emissions nationally entail both potential advantages and concerns about equity and capacity'. ${ }^{68}$ Table 4.1 lists policy instruments to cut carbon dioxide emissions: cap-and-trade permits, emissions targets, taxes or charges, subsidies for renewables, subsidy cuts, performance standards, technology standards, and better information. The only ones with positive comments on 'equity aspects'

\footnotetext{
${ }^{65}$ Overview (note 13 above) 11.

${ }^{66} \mathrm{lbid}$.

${ }^{67}$ lbid.

${ }^{68}$ Ibid 69.
} 
are: subsidy cuts and better information. However, the report does not say where these cuts are going to happen, whether in developing or developed countries, nor is there any treatment of intra-country emissions inequalities across diverse social groups and sectors. The report's focus on action in developing countries, where cutting of emissions may sometimes have an inverse relationship with equity (due to the relation that the report has showed between development and access to water, sanitation and energy), leads to claims which are then excessively generalised, and implicitly used to reduce the pressure for adjustments in advanced economies, who are anyway not openly discussed.

More broadly, the proposed win-win-win measures for averting environmental degradation include expanding reproductive choice, promoting community forest management, and adaptive disaster response, among others. Reproductive choice is presented as a precondition of women's empowerment, and, for reasons touched on earlier, as favourable for averting environmental degradation. Community forest management could, proposes the report, redress local environmental degradation and mitigate carbon emissions, though one must beware exclusionary processes inside communities through which disadvantaged groups may be marginalised. The third measure mentioned is the development of equitable and adaptive disaster responses and innovative social protection schemes.

The options mentioned in the report are important, but remain diffuse and indirect. They do not directly address issues of climate change. Moreover they do not provide longterm vision and fail to take into account the possibility of a high-end increase in average temperatures, which will make most of the win-win-win proposals in this section unfeasible. In addition, these are again measures applied at the very local levels in developing countries, excluding the global level, as if measures in developed countries had no impact on the environment, although the data given earlier has made clear that such measures would have a stronger impact in comparison with measures in developing countries. Thinking about measures in developing countries is essential, but leaving invisible the responsibilities of developed countries on these issues is unjustifiable.

\section{(e) Section on 'Rethinking our development model - levers for change'}

This section in the Overview presents a 'new vision for promoting human development 
through the joint lens of sustainability and equity'. ${ }^{69}$ For the local and national levels, the report stresses 'the need to bring equity to the forefront of policy and programme design and to exploit the potential multiplier effects of greater empowerment in legal and political arenas'. ${ }^{70}$ For the global level, the report highlights 'the need to devote more resources to pressing environmental threats and to boost the equity and representation of disadvantaged countries and groups in accessing finance'. ${ }^{71}$

Although this section declares it is about rethinking our development model, these proposals are from a very longstanding development agenda. The global and international levels are again presented only as spaces for mobilisation of finances and not as spaces where rethought structures and systems can be designed and implemented. This section (as well as the corresponding full chapter in the report) presents the biggest challenges for a sustainable future as concerning changes in the global South, not changes in models of development in the North.

More specifically, the report presents the following ideas: ${ }^{72}$ (1) Integrating equity concerns into green economy policies: with reference not only to people's incomes but to nonincome dimensions of well-being, indirect effects of policy, compensation mechanisms for adversely affected people, and the risks of extreme weather events; (2) Embedding environmental rights in national constitutions and legislation, as well as empowering institutions to work with these rights; (3) Participation and accountability: 'greater empowerment can bring about positive environmental outcomes equitably', ${ }^{73}$ by making national institutions accountable; for example, it stresses the need to 'strengthen the possibilities for some traditionally excluded groups, such as indigenous peoples [and women], to play a more active role'. ${ }^{74}$

These ideas bring together what has been already presented in the Overview, rather than transcend it as the section's title could have implied. The attractions and limitations remain the same. First, the links drawn with the environment and especially with climate change are vague. Second, the report takes for granted the concept of green economies as a positive one without distributional consequences (in contrast, see the United Nations

\footnotetext{
${ }^{69}$ Ibid 12.

${ }^{70} \mathrm{lbid}$.

${ }^{71}$ lbid.

72 lbid.

${ }^{73}$ Ibid.

${ }^{74}$ lbid.
} 
Research Institute for Social Development (UNRISD) study on the social dimensions of the green economy). ${ }^{75}$ Third, these measures focus on local and national levels in developing countries, and do not address the main problems around climate change, which is probably the main threat to sustainability. An exception to this limitation is found in the following subsection, which proposes a currency transactions tax.

\section{Subsection on 'Closing the funding gap'}

This subsection argues that the investments needed are large but not disproportionate in relation to current spending on other sectors, let alone on the military and least of all in comparison with speculative money flows. In order to reduce the funding gap, a currency transaction tax is suggested. According to the report, 'at a very minimal rate ( 0.005 percent), and without any additional administrative cost, the currency transaction tax could yield additional annual revenues of about $\$ 40$ billion' ${ }^{76}$ An additional mechanism suggested is the monetization of part of the IMF surplus Special Drawing Rights.

In this one area the report makes a proposal, the currency transaction tax, that matches the global scale and character of the environmental dangers highlighted by repeated international studies like the Millennium Ecosystem Assessment (2005), the UNEP Global Environmental Outlook studies $(2007,2011)$ and the reports of the IPCC (2007). ${ }^{77}$ In other areas it remains significantly limited in its policy agenda. For example, when it argues 'for large transfers of resources to poor countries, both to achieve more equitable access to water and energy and to pay for adapting to climate change and mitigating its effects', ${ }^{78}$ the term 'mitigation' has, without comment, evolved from its normal use in climate discussions, namely the reduction of emissions of GHGs, to instead refer to mitigation of the effects of the resultant climate change. Remarkably, the Overview addresses only the effects of climate change, not the causes, ie matters that especially concern the behaviour and responsibilities of governments in wealthy countries and of affluent consumers and corporations in all countries.

The Overview uses the terms 'mitigate', 'mitigation' or 'mitigating' only five times, and

\footnotetext{
${ }^{75}$ UNRISD 'Social Dimensions of Green Economy and Sustainable Development' (2012).

${ }_{77}^{76}$ Overview (note 13 above) 13.

${ }_{77}$ Millennium Ecosystem Assessment (2005) <http://www.unep.org/maweb/en/index.aspx>; UNEP Global Environmental Outlook studies (2007, 2011) <http://www.unep.org/geo/>; and the reports of the IPCC (2007) $<$ http://www.ipcc.ch/publications_and_data/publications_and_data_reports.shtml\#1>.

${ }^{78}$ Overview (note 13 above) 13.
} 
never specifically to refer to reduction of GHG emissions in rich countries or by rich producers and consumers. Indeed only one of the five uses even permits such reference; the others are about developing countries or 'mitigation of effects'. These terms are used 27 times in total in the full report, plus 10 times in References and Notes. From the 27 uses, 10 are clearly related to mitigation of the effects of climate change, or are used ambiguously, and 11 more are linked to financing mitigation or mitigation costs. Four cases refer to mitigation of carbon emissions, but it is not clear in which countries, and two uses are not related to climate change at all. Considering that the report mostly focuses on developing countries, it can be inferred that usage of the term is largely linked to mitigation of effects of climate change or mitigation of carbon emissions taking place in developing countries.

\section{(ii) Subsection on 'Reforms for greater equity and voice'}

The last subsection of the Overview discusses reforms for greater equity and voice. It remarks that accountability is not sufficient but is a necessary condition for 'building a socially and environmentally effective global governance system that delivers for people'. ${ }^{79}$ Since accountability is not sufficient, it would have been important to mention other conditions needed to reduce power imbalances and promote effective global governance. However, as when the Overview calls for '[s]upport for institution building ... so that developing countries can establish appropriate policies and incentives', ${ }^{80}$ the emphasis is on the mechanisms in developing countries, and less on international institutions and the power imbalances at that level. This holds also for the version in the full report.

The Overview then calls for 'measures to improve equity and voice in access to financial flows directed at supporting efforts to combat environmental degradation'. ${ }^{81}$ The measures are related only to the access to financial flows, and omit other relevant global political and legal instruments and norms; and the talk is of environmental degradation, rather than specifically of climate change. The proposals in the report do not strongly address climate change and its causes, and only seek to 'mitigate' some of its effects. The fashionable term 'voice' helps to hide such silences.

In conclusion, the Overview proposes four country-level sets of tools to take its agenda

\footnotetext{
79 lbid 14.

${ }^{80}$ Ibid 15.

${ }^{81}$ Ibid 14.
} 
forward: low-emission, climate-resilient strategies; public-private partnerships; climate dealflow facilities; and coordinated implementation and monitoring, reporting and verification systems. ${ }^{82}$ The final proposal is for a 'high-profile, global Universal Energy Access initiative dedicated to develop clean energy at the country level'. ${ }^{83}$

In effect, the report makes a case for not using the climate change issue to stop development advances in the underdeveloped world. It argues that: development is needed in poor countries; it can be achieved in a sustainable way; equity is both a means and a goal of development; and equity can lead to sustainability (this link is relatively weakly argued). Thus it argues that development, which is necessary for social justice, can be done without big impacts on the environment. However, it falls short in regard to the need to address more direct measures to reduce climate change, in and by the global North, or to question what type of development is good for the South in the medium and long term.

\section{Framing and Lexical Choice}

The central question this article asks is in which direction does the HDR 2011 moves in relation to the schizophrenic stance in the HDR 2007/2008 on climate change. We have established the basis for an answer by examining in detail the arguments presented in its Overview. We now synthesise that analysis by a review of the inclusions and exclusions that we have seen in the HDR 2011; and then complement this by a comparison of its chosen vocabulary with the vocabularies of the HDR 2007/2008 and, by contrast, the WDR 2010 on climate change and development, to see the direction of movement.

\footnotetext{
82 Ibid 15.

${ }^{83}$ lbid.
} 
Table 2: Spotlights and shadows - inclusions and exclusions in the HDR 2011

\begin{tabular}{|c|c|c|}
\hline THEME & INCLUSIONS AND/OR HIGHLIGHTING & EXCLUSIONS AND/OR DOWNGRADING \\
\hline Title & The vague language of 'equity' & The language of human rights \\
\hline Title & Gains for everybody & Our divided world; countering global divisions \\
\hline \multirow[t]{3}{*}{ Geographic focus } & $\begin{array}{l}\text { LDCs as a focus for analysis and policy } \\
\text { advice }\end{array}$ & DCs, global relations \\
\hline & North as a source of finance (Foreword) & $\begin{array}{l}\text { North is not otherwise a target for policy advice } \\
\text { (p.iii) }\end{array}$ \\
\hline & $\begin{array}{l}\text { National and local levels in less developed } \\
\text { countries, via focus on problems of the use of } \\
\text { land, water and forests (p.6) }\end{array}$ & $\begin{array}{l}\text { The need for changes in highly developed } \\
\text { countries, via focus on greenhouse gas emissions. }\end{array}$ \\
\hline Topic focus & Diverse environmental and poverty issues & Causes and implications of climate change \\
\hline $\begin{array}{l}\text { Topic focus: } \\
\text { Power imbalances }\end{array}$ & $\begin{array}{l}\text { Power imbalances at national level, as a policy } \\
\text { focus (Foreword) }\end{array}$ & Power imbalances at global level, as a policy focus \\
\hline $\begin{array}{l}\text { Analysis: global } \\
\text { responsibilities for } \\
\text { environmental impact }\end{array}$ & Carbon emissions per country & $\begin{array}{l}\text { P.3: the re-allocation of carbon-intensive } \\
\text { production to poor countries, while the output is } \\
\text { exported to rich countries (p.3). }\end{array}$ \\
\hline Analytical focus & $\begin{array}{l}\text { 'Win-win-win' in terms of generalized } \\
\text { objectives }\end{array}$ & $\begin{array}{l}\text { Describing the lives and livelihoods of specific } \\
\text { groups of people (as done more in HDR 2007/8) }\end{array}$ \\
\hline \multirow[t]{3}{*}{ Evaluative criteria } & $\begin{array}{l}\text { HDI (even global HDI); national (and even } \\
\text { global) averages and aggregates }\end{array}$ & Human rights, including of the worst-off groups \\
\hline & $\begin{array}{l}\text { Germany and Sweden as examples of win- } \\
\text { win-win policies }\end{array}$ & $\begin{array}{l}\text { Germany and Sweden's questionable perform- } \\
\text { ance on greenhouse gas emissions; impacts on } \\
\text { poorer groups in tropical and subtropical zones (as } \\
\text { described in the HDR 2007/8) }\end{array}$ \\
\hline & "the planet" and "future generations" (p.ii) & $\begin{array}{l}\text { Current generations of people suffering the } \\
\text { consequences of climate change and poverty }\end{array}$ \\
\hline Grouping of countries & $\begin{array}{l}\text { Very high HDI countries versus low, medium } \\
\text { and high HDI countries (p.3) }\end{array}$ & $\begin{array}{l}\text { Low HDI countries are not considered separately; } \\
\text { instead very high HDI countries are separated out }\end{array}$ \\
\hline \multirow[t]{11}{*}{ Policy focus } & $\begin{array}{l}\text { Case for not using the climate change issue to } \\
\text { stop development advances in the } \\
\text { underdeveloped world. }\end{array}$ & $\begin{array}{l}\text { Reducing climate change, especially through } \\
\text { measures in the global north. }\end{array}$ \\
\hline & $\begin{array}{l}\text { Institution building in developing countries } \\
\text { (p.15) }\end{array}$ & $\begin{array}{l}\text { International institutions and the power } \\
\text { imbalances at that level. Institutional reform in } \\
\text { rich countries }\end{array}$ \\
\hline & $\begin{array}{l}\text { 'Rethinking our development model': the } \\
\text { global and international levels as spaces for } \\
\text { mobilization of finances }\end{array}$ & $\begin{array}{l}\text { Global and international levels as spaces where } \\
\text { rethought structures and systems can be designed } \\
\text { and implemented. }\end{array}$ \\
\hline & Expanding freedoms for the weak & $\begin{array}{l}\text { Restricting those freedoms for the well-to-do } \\
\text { which damage the weak }\end{array}$ \\
\hline & $\begin{array}{l}\text { 'Mitigating the effects' of climate change, in } \\
\text { other words 'adaptation' }\end{array}$ & $\begin{array}{l}\text { Mitigation: greenhouse gas emission reduction. } \\
\text { The limits and barriers to adaptation. }\end{array}$ \\
\hline & Population limitation in the global South (p.9) & Consumption limitation in the global North \\
\hline & $\begin{array}{l}\text { Transformation in gender roles in the global } \\
\text { South (p.9) }\end{array}$ & $\begin{array}{l}\text { High greenhouse gas emissions etc. in those } \\
\text { countries where more gender equality has been } \\
\text { achieved }\end{array}$ \\
\hline & Democratization in the global South (p.10) & $\begin{array}{l}\text { Much greater environmental footprints in many } \\
\text { countries with strong democracies, implying there } \\
\text { are numerous other relevant conditions }\end{array}$ \\
\hline & $\begin{array}{l}\text { Empowerment of weaker groups in poor } \\
\text { countries (p.10) }\end{array}$ & Power imbalances between countries \\
\hline & $\begin{array}{l}\text { Finances for adaptation or mitigation of } \\
\text { effects in developing countries }\end{array}$ & $\begin{array}{l}\text { Maladaptation, the limits to adaptation. barriers to } \\
\text { adaptation, contrasting with the HDR } 2007 / 8 \\
\text { which coined the term adaptation apartheid }\end{array}$ \\
\hline & LDCs & Rich countries and rich persons \\
\hline
\end{tabular}


Table 2 brings together points from the previous two parts on the contents of the report's Foreword and Overview. Inside the frame of the HDR 2011 are least developed countries (LDCs) and a certain range of permitted issues, such as local participation, local accountability and gender equality, and wholly or largely outside the frame are rich countries, their production and consumption patterns, global relations, global participation and accountability, and the limits to feasible adaptation in poor countries, relations between adaptive capacity and governance, impacts of mitigation strategies, as well as maladaptation. In sum, the HDR 2011 is in general less questioning of the global status quo, in comparison with the HDR 2007/2008. These exclusions and inclusions become visible through repeated close reading that is guided by a checklist of concerns from critical development studies, political ecology and literature from the field of the human dimensions of global environmental change. ${ }^{84}$

\section{(a) Lexical analysis ${ }^{85}$}

While parts 2 and 3 conducted the content analysis on a paragraph-by-paragraph basis, and Table 2 reviews the findings systematically, to put figures on some of the tendencies can help to increase confidence in our assessment. We will do this by looking at the choices and frequency of use of keywords. We compare the vocabulary of the HDR 2011 to that of its 2007/2008 predecessor and their WDR 2010 competitor. In each case we confine this analysis to the report Overview.

We remarked earlier that 'climate change' is referred to only 22 times in the Overview for the HDR 2011, compared to 157 times in the Overview for the HDR 2007/2008. While allowing for the greater length of the 2007/2008 report and for the 2011 report's coverage of all aspects of environmental sustainability, this marks a significant reduction of priority to climate change in the later report. Undertaking a similar analysis for other keywords, we find that in the new report the rich or developed countries are little mentioned, and that many of

\footnotetext{
${ }^{84}$ M Bunce, K Brown \& S Rosendo 'Policy Misfits, Climate Change and Cross-Scale Vulnerability in Coastal Africa: How Development Projects Undermine Resilience' (2010) 13 Environmental Science \& Policy 485, 497; H Eakin, A Winkels \& J Sendzimir 'Nested Vulnerability: Exploring Cross-Scale Linkages and Vulnerability Teleconnections in Mexican and Vietnamese Coffee Systems' (2009) 12 Environmental Science \& Policy 398, 412; BA Beymer-Farrisa \& TJ Bassett 'The REDD Menace: Resurgent Protectionism in Tanzania's Mangrove Forests' (2012) 22 Global Environmental Change 332,341; Barnett \& O'Neill (note 39 above) 213.

${ }^{85}$ The absolute word counts presented in this section exclude the HDRs' Forewords.
} 
the distinctive features of the 2007/2008 report have disappeared, the features that marked it out as displaying a partly different field of attention and set of values than in the World Bank's comparable WDR 2010. The emphasis on children, grandchildren and future generations is gone, the poor and the world's poor are mentioned four times only, in comparison with 38 times in the HDR 2007/2008, humanity is not mentioned, and other terms such as 'social justice', 'human rights', and 'political' have almost disappeared. The words 'adaptation', 'adaptive', and 'adapt', are used only six times, plus once in the Foreword (versus 68 times in the HDR 2011), and 'mitigation' appears only four times and is used in a very ambiguous way, not referring to reduction or cutting of emissions directly. On the other hand, the terms 'equity' and 'sustain' (in all its variants) are widely used. These terms were characteristic of the 2010 WDR too: 'equity' serves as a vaguer substitute for social justice and human rights, and 'sustain' as part of a growth orientation. ${ }^{86}$

Table 3 provides a comparison of this use of key terms in the overviews of the three reports. A number of complications are faced in making the comparisons. First, the reports vary in length. In the case of the texts of the WDR 2010 Overview and the HDR 2007/2008 Overview there is little difference (with reference to the full version for the HDR Overview and after omitting References in the WDR case since the HDR Overview does not include references), but this is not the case with the HDR 2011. Table 3 therefore presents relative word frequencies rather than absolute word counts. Absolute counts are given in an appendix. They are in themselves significant, since not only the relative frequency of reference to a theme but also the absolute number of words devoted to that theme is an indicator of the importance given to it.

Second, the structures of the documents are not identical. The WDR presents a single version of the Overview, while the HDR presents two, one of which is at the start of the full version of the report, and the other of which is presented within the Summary, which is also available as a separate file on the HDR website. As mentioned earlier, this version of the Overview provides a self-contained account that also includes some additional materials from elsewhere in the report, notably selected tables, diagrams and sometimes text boxes. The WDR Overview already incorporates such materials. Further, the WDR Overview incorporates a Reference list, unlike the HDR Overview; while in the other direction, the HDR Summary

\footnotetext{
${ }^{86}$ Gasper et al (note 8 above).
} 
also incorporates the more substantial HDR Foreword and the Table of Contents, as part of the overall message that it wishes to provide in the version that it expects will be the sole encounter with the report for the majority of readers. Table 3 presents the simplest comparison: excluding in each case the Table of Contents, References, Figures and Tables, and separating out the Forewords. Other comparisons can be added, but inclusion of the additional material will not change the very sharp contrasts in vocabulary that the table reveals.

In most key respects the HDR 2011 lies clearly closer to the language of the WDR 2010 than to the language of the HDR 2007/2008. Not only does it downgrade attention to future generations, the poor, human rights, and the responsibilities of rich countries, it even drops the concept of 'humanity' which was prominent in the 2007/2008 report and which one would expect to find as part of the perspective that distinctively legitimates preparing a HDR in contrast to the more conventional economic analysis in the WDR. In a few cases, the language is unchanged from 2007/2008: the HDR 2011 does not adopt the WDR 2010's heavy use of 'efficient', 'management' and 'can', or its interest in the economic logic of insurance. It is less averse to the term 'political' than is the WDR, and retains a UN style of speaking in terms of 'we' (35 uses, compared to 56 in the HDR 2007/2008 Overview and only 11 in the WDR 2010 Overview) and of appealing for action in the face of global 'challenges'. But it no longer presents these challenges as exceptionally urgent: use of the idea of 'catastrophe' declines, and the term 'threshold' almost disappears, in both cases down to the same frequency as in the WDR 2010 Overview. 
Table 3: The languages of the three Report Overviews

\begin{tabular}{|c|c|c|c|}
\hline $\begin{array}{c}\text { TERM/PHRASE } \\
\text { Frequency of usage }^{87}\end{array}$ & $\begin{array}{l}\text { HDR 2007/8 OVERVIEW } \\
\text { [Excluding foreword, table } \\
\text { of contents, notes and } \\
\text { references] }\end{array}$ & $\begin{array}{c}\text { HDR } 2011 \\
\text { OVERVIEW } \\
\text { [Excluding foreword, table } \\
\text { of contents, notes and } \\
\text { references] }\end{array}$ & $\begin{array}{l}\text { WDR } 2010 \text { OVERVIEW } \\
\text { [Excluding table of contents, } \\
\text { notes and references] }\end{array}$ \\
\hline $\mathrm{We}$ & $0.46[0.60]$ & $0.48[0.48]$ & 0.07 \\
\hline Children / our children & $0.09[0.10]$ & $0.11[0.10]$ & 0.01 \\
\hline grandchildren & $0.02[0.03]$ & $0.01[0.01]$ & 0.00 \\
\hline future generations & $0.16[0.14]$ & $0.04[0.06]$ & 0.00 \\
\hline $\begin{array}{l}\text { the world's poor and } \\
\text { future generations }\end{array}$ & $0.05[0.04]$ & $0.00[0.00]$ & 0.00 \\
\hline $\begin{array}{c}\text { the world's poor / the } \\
\text { world's poorest }\end{array}$ & $0.21[0.19]$ & $0.00[0.01]$ & 0.00 \\
\hline $\begin{array}{l}\text { the poor / the poorest / } \\
\text { the world poorest[as a } \\
\text { noun; in addition to } \\
\text { uses of 'the world's } \\
\text { poor'] }\end{array}$ & $0.11[0.12]$ & $0.06[0.05]$ & 0.05 \\
\hline the world & $0.24[0.27]$ & $0.14[0.17]$ & 0.10 \\
\hline Humanity & $0.07[0.06]$ & $0.00[0.00]$ & 0.01 \\
\hline human rights & $0.08[0.07]$ & $0.03[0.02]$ & 0.00 \\
\hline $\begin{array}{c}\text { community/communit } \\
\text { ies }\end{array}$ & $0.10[0.11]$ & $0.17[0.19]$ & 0.05 \\
\hline $\begin{array}{c}\text { the international } \\
\text { community }\end{array}$ & $0.02[0.03]$ & $0.03[0.04]$ & 0.00 \\
\hline global community & $0.01[0.01]$ & $0.00[0.00]$ & 0.00 \\
\hline human community & $0.02[0.01]$ & $0.00[0.00]$ & 0.00 \\
\hline Climate change & $1.29[1.26]$ & $0.30[0.28]$ & 0.48 \\
\hline justice / injustice & $0.07[0.06]$ & $0.03[0.04]$ & 0.00 \\
\hline equity / equitable & $0.02[0.01]$ & $0.82[0.84]$ & 0.10 \\
\hline $\begin{array}{c}\text { political/politically/po } \\
\text { litics }\end{array}$ & $0.17[0.17]$ & $0.11[0.11]$ & 0.04 \\
\hline $\begin{array}{l}\text { 'efficiency'/'efficient' } \\
\text { /'inefficient'/'inefficie } \\
\text { ncy / inefficiencies }\end{array}$ & $0.16[0.15]$ & $0.03[0.02]$ & 0.31 \\
\hline 'climate smart' & $0.00[0.00]$ & $0.00[0.00]$ & 0.06 \\
\hline Threshold/s & $0.06[0.05]$ & $0.01[0.01]$ & 0.01 \\
\hline $\begin{array}{c}\text { Catastrophe/s/catastro } \\
\text { phic }\end{array}$ & $0.09[0.09]$ & $0.04[0.04]$ & 0.05 \\
\hline $\begin{array}{c}\text { insurance, insurers, } \\
\text { insure }\end{array}$ & $0.02[0.04]$ & $0.00[0.00]$ & 0.11 \\
\hline $\begin{array}{c}\text { Challenge/s / } \\
\text { Challenging }\end{array}$ & $0.16[0.19]$ & $0.21[0.22]$ & 0.07 \\
\hline Can & $0.26[0.25]$ & $0.36[0.35]$ & 0.51 \\
\hline $\begin{array}{c}\text { manage/(mis)manage } \\
\text { ment/mismanaging }\end{array}$ & $0.06[0.06]$ & $0.06[0.05]$ & 0.28 \\
\hline $\begin{array}{l}\text { Rich countries / rich } \\
\text { nations / rich world/ } \\
\text { the rich/er }\end{array}$ & $0.21[0.20]$ & $0.03[0.02]$ & 0.01 \\
\hline
\end{tabular}

${ }^{87}$ Word frequency including the Foreword is in brackets. The WDR does not include a detailed foreword, only a brief statement from the president of the World Bank, which is not analysed here. Table of Contents, Notes and References are excluded from the frequency counts. 


\begin{tabular}{|c|c|c|c|}
$\begin{array}{c}\text { Developed country/ies } \\
\text { / world }\end{array}$ & $0.14[0.12]$ & $0.01[0.01]$ & 0.03 \\
\hline Mitigation/mitigating & $0.30[0.29]$ & $0.06[0.06]$ & 0.57 \\
\hline $\begin{array}{c}\text { economic growth [or } \\
\text { growth meaning } \\
\text { economic growth] }\end{array}$ & $0.11[0.09]$ & $0.07[0.07]$ & 0.16 \\
\hline effective/effectiveness & $0.02[0.01]$ & $0.12[0.11]$ & 0.13 \\
\hline consumption & $0.05[0.04]$ & $0.04[0.05]$ & 0.13 \\
\hline sustain [in all variants] & $0.26[0.22]$ & $0.57[0.62]$ & 0.07 \\
\hline tipping points & $0.02[0.01]$ & $0.03[0.02]$ & 0.01 \\
\hline fight / fighting & $0.05[0.04]$ & $0.00[0.00]$ & 0.00 \\
\hline financ/e/es/ing/ed/ial & $0.26[0.23]$ & $0.30[0.32]$ & 0.19 \\
\hline $\begin{array}{c}\text { investment/s/ } \\
\text { investor/s }\end{array}$ & $0.20[0.21]$ & $0.14[0.15]$ & 0.35 \\
\hline $\begin{array}{c}\text { adapt/adaptation/adapt } \\
\text { ive }\end{array}$ & $0.56[0.52]$ & $0.08[0.09]$ & 0.12 \\
\hline $\begin{array}{c}\text { Reduce - cut(ing) } \\
\text { /emissions - } \\
\text { greenhouse }\end{array}$ & $0.21[0.19]$ & $0.01[0.01]$ & \\
\hline
\end{tabular}




\section{Implications of the RePORT's Framing FOR AfRica AND SOUTH Africa}

Downgrading attention to future generations, the poor, human rights, and the responsibilities of rich countries, along with a focus on technocratic proposed win-win-win synergies between environment and (an instrumental view of) equity and human development, will have serious consequences for sub-Saharan Africa, including for South Africa and especially the poorest groups. We suggest that the report's re-framing of sustainability and its weak treatment of the absolute importance of climate change impacts in the region leads to an insufficient and sometimes misleading picture of the problems faced by the most vulnerable groups. The substantial changes in language, in the framing of the problems and in the solutions offered in the HDR 2011, compared to the HDR 2007/2008, blind the reader to existing systemic socioeconomic failures and to constraints on an appropriate balance between economic and environmental issues. In this part we unpack the treatment the report as a whole gives to South Africa and pay particular attention to the implications for South Africa's poor.

First, the Overview - the report's key chapter, that reflects the priority concerns of its controllers - only mentions African countries when identifying the likely reduction in human development that environmental degradation and increased climate change impacts will bring to the region. ${ }^{88}$ Desertification and deforestation are highlighted as particular worries. ${ }^{89}$ But beyond some thin references to the importance of gender equity for sub-Saharan Africa, little else is said about what the HDR 2011 perspective offers to Africa's poor.

The report fails to address properly the fact that for African countries sustainability cannot be disassociated from the pressure that climate change impacts pose. Multiple stressors make climate a development challenge that calls for addressing underlying causes of vulnerability rather than glossing over them. In particular, the report downplays socioeconomic, political and institutional factors that limit adaptive capacity and pose barriers to adaptation and resilience. Socio-economic, cultural and political vulnerabilities are recognised in climate change research as factors likely to lead to maladaptation, new vulnerabilities and increased inequalities for Africa's poorest sectors. ${ }^{90}$ Moreover, climate impacts in the African

\footnotetext{
${ }^{88}$ HDR 2011 (note 11 above) 2.

${ }^{89}$ lbid 5-6.

${ }^{90}$ M Boko et al 'Africa Climate Change 2007: Impacts, Adaptation and Vulnerability' in ML Parry, OF Canziani, JP Palutikof, PJ van der Linden \& CE Hanson (eds) Contribution of Working Group II to the Fourth Assessment
} 
continent, if average global temperatures rise close to or above two degrees, are likely to be much stronger, and frequently devastating. For example the likelihood of drying for southern Africa increases dramatically as average temperatures rise more than $2{ }^{\circ} \mathrm{C} .{ }^{91}$ Agricultural and food production may be seriously compromised leading to deep food insecurity. Changes in disease vectors, increased cases of malnourishment, and diseases related to extreme events will increase pressures in already weak health systems. ${ }^{92}$ The likelihood of conflicts and ethnic tensions due to declining access to resources is likely to increase, jeopardising the prospect of achieving sustainable and peaceful futures. ${ }^{93}$ Forced migration due to environmental pressures and changes in livelihoods patterns are also well known consequences of climate impacts, a theme that was well explored in the 2007/2008 report. ${ }^{94}$ Also absent in the 2011 report are the problems in the increasingly overcrowded cities of the developing world. And last, the report fails to consider high-end temperature scenarios. Authoritative research shows the impacts of three or four degrees average temperature increase and associated changes in precipitation patterns in the African continent as being dramatic for its socio-economic systems. ${ }^{95}$ The report's talk of win-win-win strategies leads to complacency rather than preparedness.

The treatment of less developed countries is in general skewed towards an excessively optimistic picture that hides serious risks and reasons for concern that were documented in detail in the Fourth IPCC Report. ${ }^{96}$ With the exception of a single reference to the negative effects of extreme events, ${ }^{97}$ the HDR 2011 also fails to take into account the impacts of extreme events in the region. These are well documented in the IPCC Special Report on Extreme Events (SREX), whose summary for policy-makers was released prior to the HDR,

Report of the Intergovernmental Panel on Climate Change (2007) 433, 468; G Ziervogel \& A Taylor 'Feeling Stressed: Integrating Climate Adaptation with Other Priorities in South Africa' (2008) 50 Environment 32, 41.

${ }^{91}$ C Williams, R Kniveton, \& R Dominic (eds) African Climate and Climate Change Physical, Social and Political Perspectives (2011).

${ }^{92}$ A Costello et al 'Managing the Health Effects of Climate Change' (2009) 373 Lancet 1693, 1733.

${ }^{93} \mathrm{C}$ Hendrix \& S Glaser 'Trends and Triggers: Climate, Climate Change and Civil Conflict in sub-Saharan Africa' (2007) 26 Political Geography 695, 715; C Devitt \& R Tol 'Civil War, Climate Change, and Development: A Scenario Study for sub-Saharan Africa' (2012) $49 \mathrm{~J}$ of Peace Research 129,145.

${ }_{94}^{4}$ O Brown, A Hammill \& R Mcleman 'Climate Change as the "New" Security Threat: Implications for Africa' (2007) 83 Int Affairs 1141, 1154.

${ }^{95}$ For example, $\mathrm{R}$ James \& R Washington 'Changes in African Temperature and Precipitation Associated with Degrees of Global Warming' (2012) Climatic Change.

${ }^{96}$ IPCC 'Climate Change 2007 Synthesis Report. Contribution of Working Groups I, II and III to the Fourth Assessment Report of the Intergovernmental Panel on Climate Change' [Core Writing Team RK Pachauri \& A Reisinger (eds)] (2007).

${ }^{97}$ HDR 2011 (note 11 above) 9. 
and in the report on disaster risk also published early in $2011 .{ }^{98}$ Thus the overall framing of the options for a sustainable future in Africa is neither revealing of specific negative conditions attached to low levels of human development, nor sufficiently cautious given the very high risks to food, health and water security, and disaster preparedness and reconstruction that are documented in the SREX, and the substantive changes in precipitation and other likely impacts related to high-end scenarios.

An analysis of references to the region in the overall report unveils an uneven treatment of the structural problems responsible for high inequalities and persisting poverty in Africa. References to South Africa appear mainly in relation to positive synergies and winning strategies for the environment, equity and human development. There are zero references to the continent in the chapter that discusses the limits to human development, although much climate change scholarship has shown how poverty conditions and low levels of human development are central factors for vulnerability to environmental change and of paramount importance in limiting adaptation options. While references to South Africa's particular challenges for the poor are absent in the chapters dedicated to poverty or the limits to human development (Chapters 1 and 3), South Africa figures in chapters dedicated to success stories and focused on positive synergies (as in Chapters 4 and 5).

Most references to South Africa present an unrealistic picture that hides structural conditions and inequalities that act as barriers and limits to resilience and sustainability. The report talks about expanding access to energy through massive investments in coal-fired plants, such as the World Bank's US\$3,75-billion loan to build South Africa's Medupi coal plant, and mentions the 'concerns about greenhouse gas emissions and environmental degradation as well as carbon lock-in when the longevity of infrastructure prolongs the use of obsolete technologies'. ${ }^{99}$ But it also presumes such investments will lead to access to energy for poor people, assuming that lack of access to energy in South Africa is only related to availability and not to distributional biases. As Patrick Bond details, there has already been a sharp increase in electricity prices to pay for the building of this plant, in a country where the vast majority of poor people can hardly pay existing prices. ${ }^{100}$ Eskom, South Africa's main electricity company, subsidises huge amounts of energy supply to mining corporations, who

\footnotetext{
${ }^{98}$ IPCC 'Managing the Risks of Extreme Events and Disasters to Advance Climate Change Adaptation (SREX)' (2011); UNISDR 'Disaster Risk Reduction in the United Nations' (2011).

${ }_{99}$ HDR 2011 (note 11 above) 68.

100 P Bond Politics of Climate Justice: Paralysis Above, Movement Below (2011).
} 
pay the lowest energy prices in the world. Expansion along existing lines does not increase jobs, gives no special treatment or effort to assure access to energy for the poor, and the environmental pollution associated with the building and functioning of these coal-fired plants systematically harms poor people. ${ }^{101}$

The report advocates a:

high-profile, global Universal Energy Access Initiative with advocacy and awareness and dedicated support to developing clean energy at the country level. Such an initiative could kick start efforts to shift from incremental to transformative change. ${ }^{102}$

These claims are decontextualized from existing conditions that prevent access to energy and other basic needs and that act as barriers. The use of the term transformative is thus misplaced, since in the literature it refers to drastic changes to the conditions that produce and perpetuate exclusion. ${ }^{103}$

Similarly, the report presents South Africa as a successful example in integrating the goals of social protection, climate change adaptation and disaster risk reduction in relationship to water management. South Africa's Working for Water Programme, the report argues, includes 'an environmental component, increased stream flows and water availability, improved land productivity and biodiversity in some ecologically sensitive areas'. ${ }^{104}$ Even if this programme is an excellent example of conservation that at the same time provides jobs for poorer groups, the absence of a discussion of the deep-rooted problems of lack of access to water and the environmental injustices that plague millions of poor South Africans leads to an unrealistic picture of the feasibility of a sustainable future. ${ }^{105}$

The HDR 2011's focus on win-win-win strategies fails to acknowledge existing inequalities in access to energy and other basic needs, and the forces that generate and perpetuate them, while it highlights the very small advances through fiscal reforms that tax some environmental services. ${ }^{106}$ The report further highlights South Africa's claimed success in enforcing environmental rights whereas another article in this Special Issue documents

\footnotetext{
${ }^{101}$ N Bassey To Cook a Continent: Destructive Extraction and the Climate Crises in Africa (2012); D Hallowes Toxic Futures: South Africa in the Crises of Energy, Environment and Capital (2011).

102 HDR 2011 (note 11 above) 15.

${ }^{103}$ K O'Brien 'Global Environmental Change II: From Adaptation to Deliberate Transformation' (2012) 36

Progress in Geography 667, 676; M Pelling From Resilience to Transformation (2011).

104 HDR 2011 (note 11 above) 78.

105 Bassey (note 101 above); P Bond (note 100 above); Hallowes (note 101 above).

${ }^{106}$ HDR 2011 (note 11 above) 8.
} 
poor performance of the legal system in relation to the environment. ${ }^{107}$ We find a particular mention of how the Constitution of the Republic of South Africa, 1996 guarantees the right of access to any information. ${ }^{108}$ But the report remains silent on the underlying processes that reduce freedom and capacity of individuals and groups to respond to information, including illness, illiteracy, innumeracy, and fear for personal safety.

The HDR 2011 treatment of models for rethinking development says next to nothing about the concerns expressed by many civil society organisations about the misuse of the concept 'green economies' in ways that undermine rather than promote sustainable development. Key concerns include the abuse of biofuels, land grabbing, and negative effects of much economic activity labelled as 'green', more commodification of nature, and even more conditionalities and new forms of protectionism. ${ }^{109}$

In short, the depiction of Africa, and in particular South Africa, in this report is not realistic and may lead to complacency and poor national policy-making that remains blind to structural problems and power imbalances responsible for limiting freedoms and capabilities of millions of poor South Africans. It is a different treatment of the problems and opportunities in the region than the one presented in the HDR 2007/2008, and suggests a substantive shift in thinking in the UNDP HDRO.

\section{CONCLUSION}

This article asked in which direction the thinking on environment and sustainability by UNDP's HDRO has evolved since the HDR 2007/2008, which combined a radical human rights-based diagnosis and critique with a largely conventional economic set of policy proposals, mostly close to those in the WDR 2010. Frame analysis of HDR 2011 indicates its convergence towards a World Bank perspective: inside the frame are LDCs and a certain range of permitted issues, including 'extending freedoms', while largely outside the frame are rich countries, global relations, restricting some freedoms, and even, to a surprising and disturbing extent, climate change mitigation. Mitigation of GHG emissions substantially disappears from

\footnotetext{
107 J Dugard \& A Alcaro 'Let's Work Together: Environmental and Socio-Economic Rights in the Courts' this Special Issue of S. African J. on Human Rights.

${ }^{108}$ HDR 2011 (note 11 above) 87.

109 UNRISD 'Social Dimensions of Green Economy and Sustainable Development' (2011) $<$ http://www.unrisd.org/greeneconomy>.
} 
view and is replaced by talk of 'mitigation of effects'. At the same time, the structural conditions that limit adaptation to the impacts of climate change and prevent resilience, conditions that may lead also to maladaptation and generation of new vulnerabilities, are never addressed. Lexical analysis, the comparison of word choices, corroborated this picture.

The HDR 2011 is surprisingly muted on issues of climate change, and does not address key aspects including the need to radically cut GHG emissions. On the contrary, the report takes a conservative position on the issue of cutting emissions, focusing more on expanding access to energy in developing countries in a sustainable way, and neglecting measures to decrease the current impact of unsustainable emissions. Climate change is underemphasised in the report, partially displaced by the concept of environmental sustainability. This takes away urgency from addressing the existing development pathways in the advanced economies primarily responsible for emissions, and thus can be seen as a step backwards. Additionally, the concept of sustainable human development used in the report is formulated in a far weaker way in comparison to the 1987 Bruntland Commission version, by focusing on 'reasonable' efforts instead of outcomes, and by implicitly accepting infringement of future generations' substantive freedoms. In the 2007/2008 report, in contrast, the case for radical action was forcefully made.

The HDR 2011's area of main focus is the relationship between environmental degradation and the promotion of human development, including issues of gender and democratic participation. Not all the links it proposes there are strong, and some are problematic. Emphasis on the political dimensions of climate change and poverty is given only for the local and national levels, leaving invisible the issues of power at the global level. The change of focus in the 2011 report in comparison to the 2007/2008 report is such that the HDR 2011 even - astonishingly - ignores the HDR 2007/2008 when mapping earlier contributions in HDRs on environmental sustainability. Listed on page 14 of the full report are the HDR 1990, the HDR 1994 and the HDR 2010 that emphasised the links between sustainability and human development. Extraordinarily, unmentioned in this brief history is the HDR 2007/2008 devoted to climate change.

Overall the HDR 2011 appears a severely diluted successor to the HDR 2007/2008, and much closer in perspective to the World Bank. This resolution of the 2007/2008 report's schizophrenia is consistent with the backgrounds of the staff who were in charge for 2011. The 2007/2008 report was led by the then head of the HDRO, Kevin Watkins, a political 
economist who had worked for 20 years in research and programming in human rightsoriented non-governmental development organisations, in particular the Catholic Institute for International Relations and Oxfam UK. Watkins left HDRO in 2008. While the HDRO has editorial independence within UNDP, the head of the office is appointed by the UNDP administrator, in this case Kemal Dervis, who had earlier worked for 24 years in the World Bank. The new head was Jeni Klugman, an Australian economist who moved to the post after 16 years in the World Bank. She was lead author for the 2011 report. Also prominent in the 2011 report team was the HDRO head of research, Francisco R Rodriguez, a Venezuelan economist on leave from Wesleyan University in the US, who took up the HDRO post in 2008 and left for the Bank of America Merrill Lynch in 2011. ${ }^{110}$ Klugman returned to the World Bank in 2011. Even some sections in the World Bank now appear bolder than was the HDR 2011, as can be seen in one new World Bank report. ${ }^{111}$

The disappearance of a human rights-based approach from the HDRO work on sustainability is not an incidental detail in this story. A rights-based approach stresses the fundamental importance of basic dignity for all, as something that is not to be traded-off against more consumption benefits for the already affluent. This means that equity is to be seen as an issue with intrinsic importance, and not only instrumental. Human rights-based approaches insist on as far as possible specifying and institutionalising systems of obligations to respect and promote basic rights. And they systematically track the causal chains behind rights violations and failures or inabilities to act on obligations, rather than turning one's face away from matters that might be embarrassing for powers-that-be. The deficiencies of the HDR 2011 in all these respects reflects its failure to build on the HDR 2007/2008's rightsbased problem diagnosis and to extend it into a rights-based, or at least rights-inspired, approach to policy design. We concluded our analysis of the HDR 2007/2008 with the suggestion that perhaps a different, more widely consultative, mode of report writing could have led to overcoming the gap between its stated values and its policy orientation. ${ }^{112}$ The present analysis of the HDR 2011 may suggest that the spirit in which the HDRO was created, to be an independent think-tank able to boldly move forward the debates on development strategy and development cooperation, is now in jeopardy.

\footnotetext{
${ }_{111}^{110}$ See <http://caracaschronicles.com/2011/10/21/why-chavez-will-win/>.

111 World Bank 'Turn Down the Heat: Why a $4^{\circ} \mathrm{C}$ Warmer World Must be Avoided' (2012).

112 Gasper et al (note 8 above).
} 
APPENDIX: Usage of keywords in the three Reports' Overviews ${ }^{113} 114$

\begin{tabular}{|c|c|c|c|}
\hline $\begin{array}{l}\text { TERM/PHRASE } \\
\text { Absolute ocurrence }\end{array}$ & HDR 2007/8 OVERVIEW & $\begin{array}{l}\text { HDR } 2011 \\
\text { OVERVIEW }\end{array}$ & WDR 2010 OVERVIEW \\
\hline $\mathrm{We}$ & $56[28]$ & $35[4]$ & 11 \\
\hline Children / our children & $11[3]$ & $8[0]$ & 2 \\
\hline grandchildren & $3[1]$ & $1[0]$ & 0 \\
\hline future generations & $19[0]$ & $3[2]$ & 0 \\
\hline $\begin{array}{l}\text { the world's poor and } \\
\text { future generations }\end{array}$ & $6[0]$ & 0 & 0 \\
\hline $\begin{array}{l}\text { the world's poor / the } \\
\text { world's poorest }\end{array}$ & $25[1]$ & $0[1]$ & 0 \\
\hline $\begin{array}{l}\text { the poor / the poorest / } \\
\text { the world poorest[as a } \\
\text { noun; in addition to } \\
\text { uses of 'the world's } \\
\text { poor'] }\end{array}$ & $13[4]$ & $4[0]$ & 8 \\
\hline the world & $29[8]$ & $10[4]$ & 15 \\
\hline humanity & $8[0]$ & $0[0]$ & 1 \\
\hline human rights & $10[0]$ & $2[0]$ & 0 \\
\hline $\begin{array}{c}\text { community/communit } \\
\text { ies }\end{array}$ & $12[3]$ & $12[3]$ & 8 \\
\hline $\begin{array}{c}\text { the international } \\
\text { community }\end{array}$ & $2[2]$ & $2[1]$ & 0 \\
\hline global community & $1[0]$ & $0[0]$ & 0 \\
\hline human community & $2[0]$ & $0[0]$ & 0 \\
\hline Climate change & $157[18]$ & $22[1]$ & 71 \\
\hline justice / injustice & $8[0]$ & $2[1]$ & 0 \\
\hline equity / equitable & $2[0]$ & $59[9]$ & 15 \\
\hline $\begin{array}{c}\text { political/politically/po } \\
\text { litics }\end{array}$ & $21[2]$ & $8[1]$ & 6 \\
\hline $\begin{array}{c}\text { 'efficiency'/'efficient' } \\
\text { /'inefficient'/'inefficie } \\
\text { ncy / inefficiencies }\end{array}$ & $20[1]$ & $2[0]$ & 46 \\
\hline 'climate smart' & $0[0]$ & $0[0]$ & 9 \\
\hline Threshold/s & $7[0]$ & $1[0]$ & 1 \\
\hline $\begin{array}{c}\text { Catastrophe/s/catastro } \\
\text { phic }\end{array}$ & $11[2]$ & $3[0]$ & 8 \\
\hline $\begin{array}{l}\text { insurance, insurers, } \\
\text { insure }\end{array}$ & $3[3]$ & $0[0]$ & 16 \\
\hline $\begin{array}{c}\text { Challenge/s / } \\
\text { Challenging }\end{array}$ & $20[6]$ & $15[3]$ & 11 \\
\hline Can & $32[3]$ & $26[2]$ & 75 \\
\hline $\begin{array}{l}\text { manage/(mis)manage } \\
\text { ment/mismanaging }\end{array}$ & $7[1]$ & $4[0]$ & 42 \\
\hline $\begin{array}{l}\text { Rich countries / rich } \\
\text { nations / rich world/ } \\
\text { the rich/er }\end{array}$ & $25[3]$ & $2[0]$ & 1 \\
\hline $\begin{array}{l}\text { Developed country/ies } \\
\text { / world }\end{array}$ & $17[0]$ & $1[0]$ & 4 \\
\hline
\end{tabular}

113 The word counts do not include table of contents, notes and references.

${ }^{114}$ We present here the word count of the forewords of the HDRs in brackets. The WDR does not include a foreword. 


\begin{tabular}{|c|c|c|c|} 
Mitigation/mitigating & $37[3]$ & $4[1]$ & 84 \\
\hline $\begin{array}{c}\text { economic growth [or } \\
\text { growth meaning } \\
\text { economic growth] }\end{array}$ & $13[0]$ & $5[1]$ & 24 \\
\hline effective/effectiveness & $2[0]$ & $9[0]$ & 19 \\
\hline consumption & $6[0]$ & $3[1]$ & 19 \\
\hline sustain [in all variants] & $31[0]$ & $41[9]$ & 1 \\
\hline tipping points & $2[0]$ & $2[0]$ & 81 \\
\hline fight/ fighting & $6[0]$ & $0[0]$ & 28 \\
\hline financ/e/es/ing/ed/ial & $32[0]$ & $22[4]$ & 52 \\
\hline $\begin{array}{c}\text { investment/s/ } \\
\text { investor/s }\end{array}$ & $24[5]$ & $10[2]$ & 17 \\
\hline $\begin{array}{c}\text { adapt/adaptation/adapt } \\
\text { ive }\end{array}$ & $68[5]$ & $6[1]$ & \\
\hline $\begin{array}{c}\text { Reduce - cut(ing) } \\
\text { lemissions - } \\
\text { greenhouse }\end{array}$ & $25[2]$ & $1[0]$ & \\
\hline
\end{tabular}

